\title{
Globe FringerUSh (Fimbristylis miliacea) CROSS Resistance to ALS-INHIBITOR HERBICIDES UNDER FIELD CONDITIONS IN IRRIGATED RICE IN THE SOUTH OF BRAZIL ${ }^{1}$
}

\author{
Resistência Cruzada de Herbicidas Inibidores da ALS em Cuminho (Fimbristylis miliacea) sob \\ Condições de Campo em Lavouras de Arroz Irrigado no Sul do Brasil
}

SCHAEDLER,C.E. ${ }^{2}$, NOLDIN, J.A. ${ }^{3}$, EBERHARDT, D.S. ${ }^{3}$., AGOSTINETTO, D. ${ }^{4}$, and BURGOS, N.R. ${ }^{5}$

\begin{abstract}
ALS-inhibiting herbicides usually provide adequate weed control in irrigated rice fields. After consecutive years of use, the Cyperaceae species, globe fringerush (Fimbristylis miliacea) began to show resistance to ALS (acetolactate synthase) inhibitors. Globe fringerush is one of the most problematic herbicide-resistant weeds in irrigated rice in the state of Santa Catarina in the South of Brazil. The objective of this research was to examine cross resistance of globe fringerush to ALS inhibitors, under field conditions. Two experiments were conducted in a rice field naturally infested with ALS-resistant globe fringerush in Santa Catarina, in the 2008/09 and 2009/ 10 cropping seasons. The experimental units were arranged in randomized complete block design, with five replicates, consisting of two factors (herbicide and dose) in a 4 × 5 factorial arrangement. ALS herbicides included bispyribac-sodium, ethoxysulfuron, pyrazosulfuron-ethyl and penoxsulam. Six-leaf globe fringerush was sprayed with herbicide doses of $0,0.5,1,2$ and $4 \mathrm{X}$ the recommended doses in a spray volume of $200 \mathrm{~L} \mathrm{ha}^{-1}$. The number of rice culm, filled and sterile grains, plant height, dry shoot biomass and grain yield were recorded. Globe fringerush control was evaluated 28 and 70 days after herbicide application (DAA); shoots were harvested at 13 weeks after herbicide application and dry weight recorded. Competition with globe fringerush reduced the number of culm and rice grain yield. The globe fringerush biotype in this field was resistant to all ALS herbicides tested. Penoxsulam had the highest level of activity among treatments at 28 and 70 DAA, but the control level was only $50 \%$ and $42 \%$, respectively, in the second year of assessment. This was not enough to prevent rice yield loss. Alternative herbicides and weed control strategies are necessary to avoid yield losses in rice fields infested with ALS-resistant biotypes of globe fringerush.
\end{abstract}

Keywords: Paddy rice, Oryza sativa, herbicide resistance, acetolactate synthase.

RESUMO - Herbicidas inibidores da ALS geralmente apresentam controle adequado de plantas daninhas em lavouras de arroz irrigado. Após anos consecutivos de uso, a espécie Cyperaceae cuminho (Fimbristylis miliacea) foi selecionada com resistência a herbicidas inibidores da ALS (acetolactato sintase). O cuminho é uma das mais problemáticas plantas daninhas resistentes a herbicidas em arroz irrigado em Santa Catarina, Brasil. O objetivo desta pesquisa foi investigar a resistência cruzada aos inibidores da ALS em cuminho em condições de campo. Experimentos foram realizados em lavoura de arroz naturalmente infestada com cuminho resistente a ALS em Santa Catarina, nas safras 2008/09 e 2009/10. As unidades experimentais foram dispostas em delineamento de blocos casualizados, com cinco repetições consistindo de dois fatores (herbicida e dose) em arranjo fatorial $4 \times 5$. Os herbicidas inibidores da ALS foram bispyribac-sodium, ethoxysulfuron, pyrazosulfuron-etyl e penoxsulam. Plantas de cuminho com seis folhas foram pulverizados com

1 Recebido para publicação em 12.3.2013 e aprovado em 15.5.2013.

Parte da tese de doutorado em Fitossanidade pela Universidade Federal de Pelotas do primeiro autor.

2 Universidade Federal do Pampa - UNIPAMPA, Itaqui-RS, Brasil, <caduschaedler@yahoo.com.br>; ${ }^{3}$ Epagri/Estação Experimental de Itajaí-SC, Brasil; ${ }^{4}$ Universidade Federal de Pelotas, Pelotas-RS, Brasil; ${ }^{5}$ University of Arkansas, Fayetteville, AR, USA. 
doses de herbicida equivalentes a 0, 0,5, 1, 2 e 4X as doses recomendadas, com volume de calda de $200 \mathrm{~L} \mathrm{ha} \mathrm{h}^{-1}$. Número de colmos, grãos cheios e estéril, estatura de planta, massa seca da parte aérea e produtividade de grãos foram avaliados na cultura do arroz. O controle de cuminho foi avaliado aos 28 e 70 dias após a aplicação do herbicida (DAA) e a massa seca da parte aérea 13 semanas após a aplicação do herbicida. A competição com cuminho reduziu o número de colmos e a produtividade de grãos de arroz. A população de cuminho nessa lavoura, foi resistente a todos os herbicidas inibidores da ALS testados. Penoxsulam apresentou maior atividade entre os tratamentos aos 28 e 70 DAA, porém o nivel de controle foi de apenas 50 e 42\%, respectivamente, no segundo ano de avaliação, não sendo suficiente para evitar perda de produtividade da cultura. Herbicidas alternativos e estratégias de controle são necessários para evitar perdas na produtividade das lavouras de arroz com infestação de cuminho resistente a herbicidas inibidores da ALS.

Palavras-chave: Arroz irrigado, Oryza sativa, resistência a herbicidas, Acetolactato sintase.

\section{INTRODUCTION}

Irrigated rice ranks third among the major cash crops in the states of Rio Grande do Sul (RS) and Santa Catarina (SC), in the South of Brazil. In these states, irrigated rice was grown in more than 1.28 million ha during the 2011/ 2012 season. Rice production has been increasing recently in Brazil. These states produced around 9.5 million ton of rice, corresponding to $76 \%$ of the total production in Brazil in the 2011/12 crop season, with an average yield of 7.4 ton ha-1 (IBGE, 2012). The high rice yields in Southern Brazil are associated with the adoption of new technologies, such as the use of high yielding cultivars and improved crop production practices. However, this level of productivity is still lower than the yield potential observed in experimental plots or that obtained by many producers. In some areas, yields up to twice the average (12-14 ton ha-1) have occurred. Unsatisfactory weed control is one of the main causes of crop yield losses. The use of herbicides is the most widely adopted weed control method; however, the increasing incidence of herbicide-resistant weeds has become a serious concern.

Currently, there are over 393 weed biotypes resistant to herbicides worldwide, involving at least 211 weedy species (Heap, 2012). In Brazil, there are 20 herbicideresistant species recorded; about $65 \%$ of these show resistance to ALS inhibitors used in soybean, maize and rice (Heap, 2012).

ALS-inhibitors are one of the most used herbicides in rice in Southern Brazil. These herbicides are used at low doses, are highly selective for the crop, have broad spectrum of weed control and favorable toxicity profile, due to the absence of the ALS enzyme in animals (Vidal \& Merotto Jr., 2001). Among the most problematic resistant weeds in irrigated rice in southern Brazil there is the globe fringerush, belonging to the Cyperaceae family, which occurs in the coastal areas of the South of Brazil (Kissmann, 2007; Runião, 2012). Globe fringerush thrives in moist areas; thus, it is abundant in wetlands, shallow canals, and rice fields. At high densities, it produces large shoot biomass, causing lodging of rice plants, thereby hindering rice harvest (Noldin et al., 2002). The selective control of this species in rice can be achieved with herbicides including ALS inhibitors. In Santa Catarina, populations of globe fringerush have developed to ALS inhibitors belonging to the sulfonylurea and pyrimidinylthiobenzoate families (Noldin et al., 2002).

The ALS enzyme is the primary target site of five classes of herbicides, namely sulfonylureas (SU), imidazolinones (IMI), triazolopyrimidines (TP), pyrimidinylthiobenzoates (PTB), and sulfonylamino-carbonyl-triazolinones (SCT) (Fischer et al., 2000). In Brazil, four classes of ALS inhibitors are recommended for irrigated rice: SU, TP, PTB or IMI, with the latter being used only in herbicide-resistant Clearfield ${ }^{\circledR}$ rice. Sulfonylurea herbicides, such as pyrazosulfuron-ethyl, are important tools for rice weed control in Santa Catarina. However, the repeated use of pyrazosulfuron has led to resistant globe fringerush biotypes, a common 
consequence of the intensive use of ALS inhibitors on other species (Burgos et al., 2001; Lamego et al., 2009; Merotto Jr. et al., 2009; Massa, et al., 2011).

Bispyribac-sodium, penoxsulam and ethoxysulfuron herbicides are ALS inhibitors also commonly used in rice fields in Brazil. These herbicides are still effective in controlling globe fringerush populations resistant to pyrazosulfuron-ethyl. The assessment of cross-resistance patterns to ALS inhibitors in globe fringerush under field condition is necessary to determine the effectiveness of other herbicides in controlling this weed and to create herbicide programs to mitigate the evolution of resistance to ALS-inhibitors. Thus, this experiment aimed to examine the cross resistance of a pyrazosulfuron-ethyl-resistant globe fringerush population to ALS inhibitors under field conditions.

\section{MATERIALS AND METHODS}

Two experiments were conducted in a rice field in Forquilhinha county $\left(28^{\circ} 79^{\prime} \mathrm{S}\right.$,
49 44' W), Santa Catarina, Brazil, from October 2008 to March 2009 and from November 2009 to April 2010. The soil consisted of heavy clay, with $2.2 \%$ of organic matter, $\mathrm{pH}$ of 4.8 , classified as an INCEPTISOL (Soil Survey Staff, 2003). This field was uniformly infested with a pyrazosulfuron-resistant globe fringerush population (Figure 1). At this location, rice was planted every year and pyrazosulfuron-ethyl was applied for at least ten years. The experiment was conducted in a randomized complete block design, with five replicates, consisting of two factors (herbicide and dose) in a $4 \times 5$ factorial arrangement. The studied herbicides included: pyrazosulfuron-ethy ${ }^{1}$ (Sirius 250 SC, Iharabras), penoxsulam ${ }^{2}$ (Ricer, Dow AgroSciences) + Iharol $^{3}$ (760 EC, Iharabras), bispyribac-sodium ${ }^{4}$ (Nominee $400 \mathrm{SC}$, Iharabras) + Veget oil ${ }^{5}$ (760 EC), ethoxysulfuron $^{6}$ (Gladium WG, Bayer) and bentazon $^{7}$ (Basagran $600 \mathrm{CS}, \mathrm{BASF}$ ) + carfentrazone-ethyl ${ }^{8}$ (Aurora 400 EC, FMC). The latter was added as a standard treatment. Herbicide doses were $0,0.5,1,2$ and $4 \mathrm{X}$ the recommended dose (Recomendações ..., 2007). The commercial doses for ALS-inhibitor

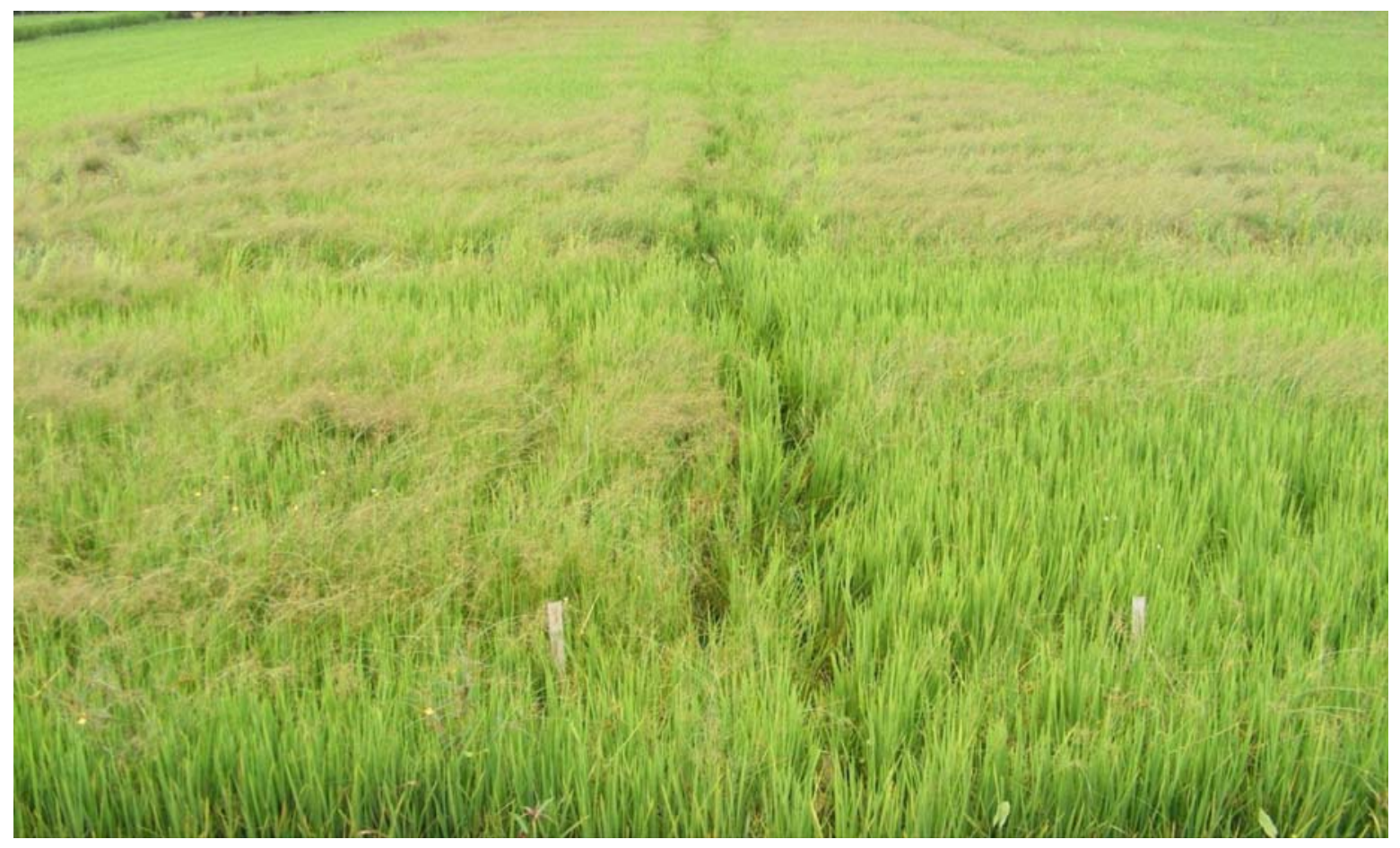

Figure 1 - Representative field experimental area of rice with infestation of globe fringerush resistant to ALS-inhibiting herbicides, in Forquilhinha, Santa Catarina, Brazil 2009/2010. 
herbicides are: $17.5,30,50$ and $80 \mathrm{~g}$ a.i. ha ${ }^{-1}$ for pyrazosulfuron-ethyl, penoxsulam, bispyribac-sodium and ethoxysulfuron, respectively. The commercial doses for bentazon + carfentrazone-ethyl are 720 and $40 \mathrm{~g}$ a.i. ha ${ }^{-1}$, respectively. Each experimental unit (plot) was $2 \mathrm{~m}$ x $5 \mathrm{~m}$. 'Epagri 109' rice seeds were pre-germinated and broadcast-planted in a flooded field at a density of 400 viable seed $\mathrm{m}^{-}$ 2, on October 23, 2008 and November 2, 2009, respectively. On both experiments, the application of fertilizer and water management were carried out according to rice production recommendations (Recomendações ..., 2007)). Nitrogen $(\mathrm{N})$ fertilizer application was evenly split: at the beginning of rice tillering and at the onset of stem elongation. Echinochloa spp. was controlled using cyhalofop-buty $1^{9}$ (Clincher 180 EC, Dow AgroScience). Herbicides were applied when globe fringerush had six leaves and rice had five leaves, using a backpack sprayer calibrated for $200 \mathrm{~L} \mathrm{ha}^{-1}$ at $200 \mathrm{kPa}$.

Rice stand, injury, number of culm, plant height, dry shoot biomass, filled and unfilled grains per panicle, and grain yield were recorded. For globe fringerush, the data collected included plant density, weed control, and dry shoot biomass. The stand of rice and globe fringerush was recorded by counting the emerged seedlings in $0.25 \mathrm{~m} \mathrm{x} 0.25 \mathrm{~m}$ quadrants, two sites per plot, at four weeks after sowing (WAS). Crop injury was recorded only in 2008/09 and weed control was visually analyzed at 14, 28, 70, 91 and $107 \mathrm{~d}$ after herbicide application (DAA) in both cropping seasons, on a scale of $0-100 \%$. Total mortality of plants was recorded as $100 \%$ control. The number of culm was recorded at 15 weeks after herbicide application (WAA) in a $0.125 \mathrm{~m}^{2}$ area at two sites per plot. Immediately after the counting, above-ground plant material was harvested from the same area. Plants were separated (rice and globe fringerush), ovendried for $72 \mathrm{~h}$ at $60{ }^{\circ} \mathrm{C}$, and dry weights were recorded. Rice panicles were harvested at 107 DAA from a $4.25 \mathrm{~m}^{2}$ area. Grain moisture content was determined and grain weight was adjusted to $13 \%$ moisture. Yield was expressed in $\mathrm{kg} \mathrm{ha}^{-1}$. Data were tested for homogeneity of variance and analyzed by ANOVA $(p \leq 0.05)$ to determine herbicide $\mathrm{x}$ dose interactions, using the Statistical Analysis System (SAS Institute, Cary, NC, USA) software. When significant difference was found, treatment means were compared using the Dunnett's test (for the number of culm) or the Fisher's test at 5\% level of probability (for unfilled grains). There were no significant year effects $(p>0.05)$, but the interaction of herbicide and dose was significant $(\mathrm{p}<0.05)$. Weed control, shoot biomass, and yield loss data were fitted with one of two sigmoidal regression models:

$$
Y=\alpha /\left(1+\left(X / X_{o} / b\right)\right.
$$

where $Y$ represents yield loss (\%) or shoot biomass, $X$ is the herbicide application rate, $\alpha$ is the maximum asymptote, $X_{0}$ is the herbicide dose required to reduce $50 \%$ yield or to reduce shoot biomass (according to $\alpha$ variable) and $b$ is the slope of the curve around $X_{0}$.

$$
\mathrm{Y}=\alpha / 1+\mathrm{e}^{-(\mathrm{X}-\mathrm{Xo}) / b}
$$

where $Y$ represents control (\%), $X$ is the herbicide application rate, $\alpha$ is the maximum asymptote, $X_{0}$ is the herbicide dose required to reduce $50 \%$ the yield or to reduce the shoot biomass (according to $\alpha$ variable), and $b$ is the slope of the curve around $X_{0}$. Sigma Plot 10.0 was used for regression analysis and curve fitting.

\section{RESULTS AND DISCUSSION}

Weed resistance pattern assessments are normally conducted in greenhouses because such experiments consist of many treatments (multiple herbicides and doses). Pot experiments in greenhouses do not always produce results identical to those of field conditions, but implementing bioassays in the field, even on small plots, would require a large area with uniform resistant weed infestation. Finding a homogeneous resistant population in the field is almost always impossible. However, we found a field in Santa Catarina that was uniformly infested with ALS-resistant globe fringerush, which was ideal for conducting this experiment under field conditions. Control ratings at 28 and 70 DAA showed resistance to ALS-inhibitor herbicides. The herbicide $x$ dose interaction was significant $(p \leq 0.05)$. The level of control increased with herbicide dose, but none of the ALS-inhibiting herbicides provided adequate globe fringerush control at the recommended dose (Table 1). The average control was 
Table 1 - Regression parameters ${ }^{1 /}$ and $\mathrm{C}_{50}$ for globe fringerush resistant to ALS inhibitor herbicides, in Forquilhinha, Santa Catarina, Brazil, 2009/2010

\begin{tabular}{|c|c|c|c|c|c|}
\hline Herbicide & Season $^{2 /}$ & $\mathrm{a}$ & $\mathrm{b}$ & $\mathrm{C}_{50^{-3 /}}$ & $\mathrm{R}^{2}$ \\
\hline & \multicolumn{5}{|c|}{28 DAA } \\
\hline \multirow{2}{*}{ Pyrazosulfuron-ethyl } & $2008 / 09$ & 17.32 & 0.18 & $>4 X$ & 0.96 \\
\hline & $2009 / 10$ & 15.01 & 0.44 & $>4 \mathrm{X}$ & 0.98 \\
\hline \multirow{2}{*}{ Bispyribac-sodium } & $2008 / 09$ & 28.60 & 0.96 & $>4 \mathrm{X}$ & 0.98 \\
\hline & $2009 / 10$ & 18.14 & 0.57 & $>4 \mathrm{X}$ & 0.95 \\
\hline \multirow{2}{*}{ Penoxsulam } & $2008 / 09$ & 63.62 & 0.76 & $>4 X$ & 0.96 \\
\hline & $2009 / 10$ & 40.04 & 0.53 & $>4 \mathrm{X}$ & 0.96 \\
\hline \multirow{3}{*}{ Ethoxysulfuron } & $2008 / 09$ & 26.40 & 0.16 & $>4 \mathrm{X}$ & 0.99 \\
\hline & $2009 / 10$ & 25.96 & 0.21 & $>4 \mathrm{X}$ & 0.98 \\
\hline & \multicolumn{5}{|c|}{$70 \mathrm{DAA}$} \\
\hline Pyrazosulfuron-ethyl & $2009 / 10$ & 12.16 & 0.63 & $>4 X$ & 0.97 \\
\hline Bispyribac-sodium & $2009 / 10$ & 5.00 & 0.08 & $>4 X$ & 0.97 \\
\hline Penoxsulam & $2009 / 10$ & 43.41 & 0.64 & $>4 \mathrm{X}$ & 0.98 \\
\hline Ethoxysulfuron & $2009 / 10$ & 10.55 & 0.45 & $>4 \mathrm{X}$ & 0.96 \\
\hline
\end{tabular}

${ }^{1 /}$ Sigmoidal model equation: $\mathrm{Y}=\mathrm{a} \mathrm{D} 1+\mathrm{e}^{-(\mathrm{X}-\mathrm{x} 0) \mathrm{r}} \cdot(\mathrm{p}<0.05) .{ }^{2 /}$ Season of the experiment. ${ }^{3 /}$ Herbicide dose that could control globe fringerush by $50 \%$.

$\leq 25 \%$ in the first year and $\leq 21 \%$ in the second year for penoxsulam and ethoxysulfuron, respectively. At the first analysis (28 DAA), 50\% control was achieved only with the $4 \mathrm{X}$ dose of penoxsulam in the first year (120 g a.i. ha-1) (Figure 2). At 70 DAA in 2009/10, weed control was at $42 \%$ with penoxsulam and only $5-12 \%$ with other herbicides (Figure 2).

Globe fringerush shoot dry weight at 13 WAA, examined only in 2009/10, was reduced with increasing herbicide dose (Figure 3). Weed biomass reduction caused by penoxsulam $(82 \%)$ was higher than that caused by other herbicides at the maximum dose of $120 \mathrm{~g}$ a.i. ha-1. The recommended dose of bispyribac-sodium (50 g a.i. ha ${ }^{-1}$ ) reduced the dry weight of globe fringerush by $13 \%$ only when compared to the nontreated plot. Pyrazosulfuron-ethyl and ethoxysulfuron equally reduced shoot dry weight, about $32 \%$, at the low doses of 17.5 and $80 \mathrm{~g}$ a.i. harespectively. Penoxsulam had the highest (but still unacceptable) control of globe fringerush in this study. Globe fringerush shoot dry weight decreased more than 50\% with half dose of penoxsulam (15 g a.i. ha-1); higher doses of up to $120 \mathrm{~g}$ a.i. ha ${ }^{-1}$ only reached up to $80 \%$ of shoot biomass reduction. Thus, none of the ALS inhibitors were effective on globe fringerush. Although globe fringerush was resistant to all the ALS inhibitors tested, the level of resistance to ALS herbicides differed. This occurred because ALS herbicide families bind to different domains in the enzyme; thus, if resistance is due to alteration(s) in the binding site, then the affinity of ALS herbicides will be affected differently (Tranel $\&$ Wright, 2002). Metabolism-based resistance would also result in different resistance levels to various ALS herbicides, depending on the detoxification pathway involved. A study on the mechanism of resistance in late watergrass, showed 2.8 times faster oxidative $\left[{ }^{14} \mathrm{C}\right]-$ penoxsulam metabolism for a resistant plant compared to $\mathrm{S}$ plants $24 \mathrm{~h}$ after treatment (Yasuor et al. 2009).

Table 2 - Regression parameters ${ }^{\underline{1}}$ and $\mathrm{C}_{50}$ for globe fringerush resistant to ALS-inhibitor herbicides at 107 days after herbicide application, in Forquilhinha, Santa Catarina, Brazil 2009/2010

\begin{tabular}{|l|c|c|c|c|}
\hline \multicolumn{1}{|c|}{ Herbicide } & $\mathrm{a}$ & $\mathrm{b}$ & $\mathrm{X}_{0} 50^{\frac{2}{}}$ & $\mathrm{R}^{2}$ \\
\hline Pyrazosulfuron-ethyl & 99.9 & 0.86 & 3.12 & 0.97 \\
\hline Bispyribac-sodium & 101.8 & 1.39 & 3.42 & 0.99 \\
\hline Penoxsulam & 100.0 & 0.56 & 0.28 & 0.99 \\
\hline Ethoxysulfuron & 101.7 & 0.83 & 3.22 & 0.99 \\
\hline
\end{tabular}

${ }^{1 /}$ Log-logistic equation: $\mathrm{Y}=$ a D $\left(1+(\mathrm{X}-\mathrm{X} 0)^{\mathrm{b}}\right) .(\mathrm{p}<0.001)$.

${ }^{2 /}$ Herbicide dose that could reduce growth of globe fringerush by $50 \%$.

Planta Daninha, Viçosa-MG, v. 31, n. 4, p. 893-902, 2013 

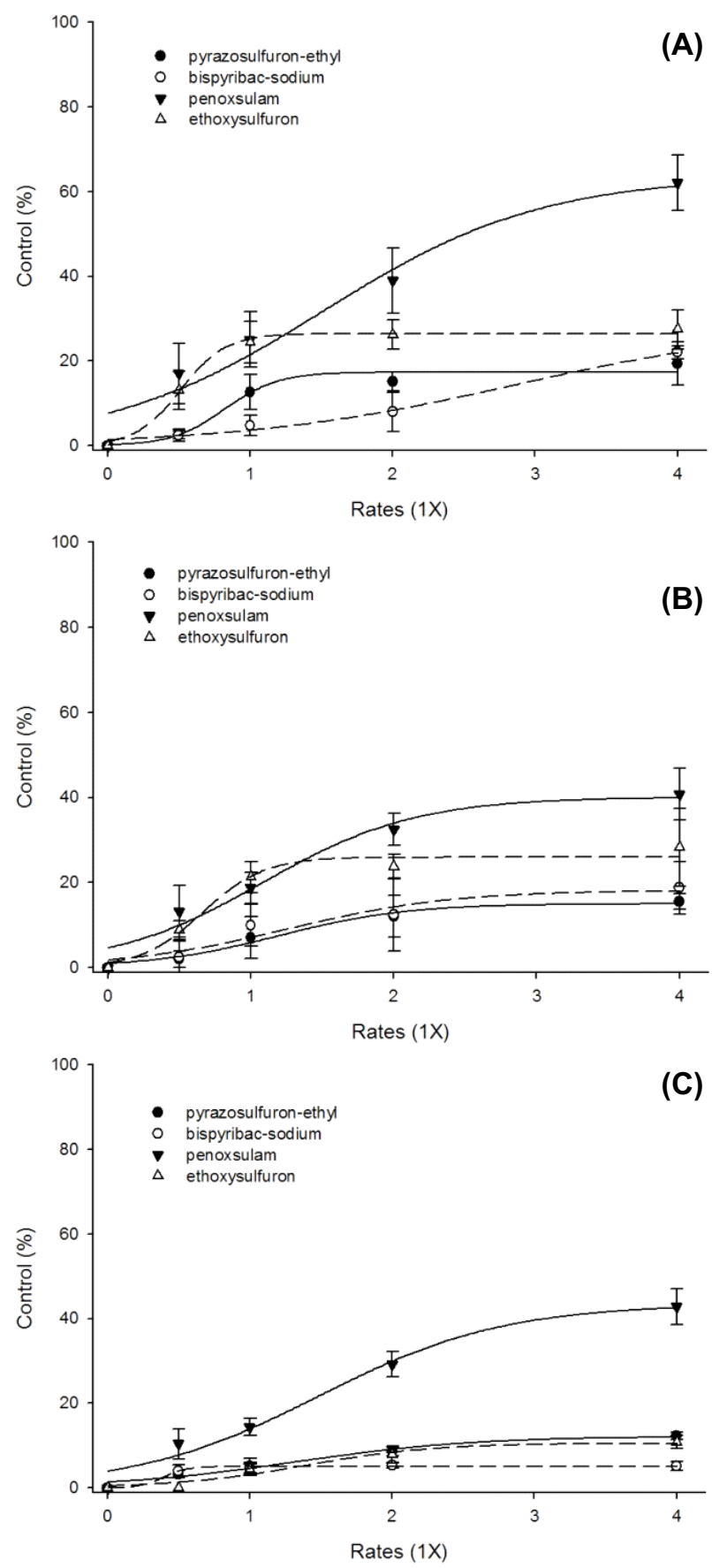

Figure 2 - Control at 28 (A B) and 70 DAT (C) of globe fringerush resistant to ALS inhibitor herbicides following POST applications of pyrazosulfuron-ethyl $(\bullet)$, bispyribac-sodium $(\mathrm{O})$, penoxsulam $(\boldsymbol{\nabla})$, and ethoxysulfuron $(\Delta)$. Vertical bars represent the confidence interval $(\mathrm{p} \leq 0.05)$. Experiments were conducted in the field, in Forquilhinha, Santa Catarina, Brazil, 2008/09 and 2009/10.

Overall, the ALS herbicides caused minimal injury to rice plants. At 28 DAA, the

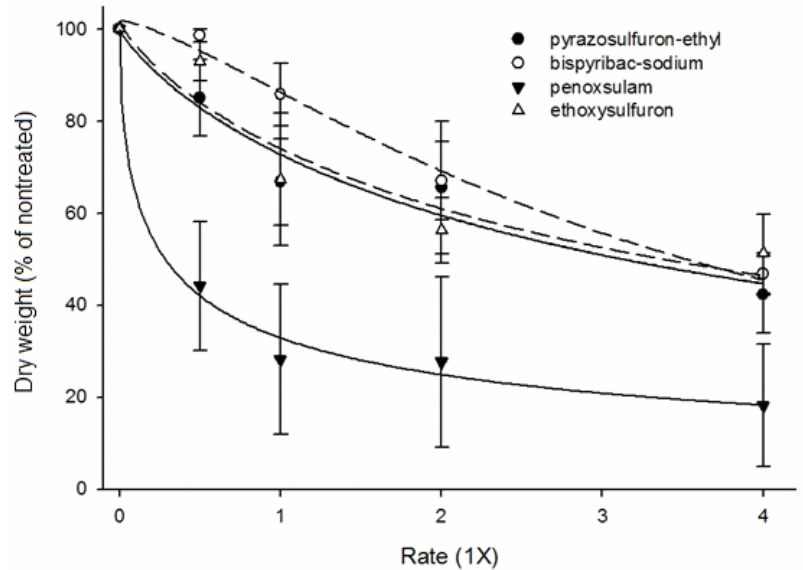

Figure 3 - Dry shoot biomass of globe fringerush resistant to ALS inhibitor herbicides, at 91 DAA, following POST applications of pyrazosulfuron-ethyl $(\bullet)$, bispyribac-sodium $(\circ)$, penoxsulam $(\boldsymbol{\nabla})$, and ethoxysulfuron $(\Delta)$. Vertical bars represent the confidence interval $(\mathrm{p} \leq 0.05)$. Experiments were conducted in the field, in Forquilhinha, Santa Catarina, Brazil 2008/2009.

highest rice injury was $6.6 \%$ with the bentazon + carfentrazone-ethyl treatment (Table 3). Injury symptoms from the tank mixture of bentazon + carfentrazone-ethyl were characterized by initial reduction in plant growth and damage on leaves. However, crop injury was minimal at all evaluation periods, with no detectable differences among treatments (data not shown). The herbicide treatments did not affect the number of filled grains, plant height and dry biomass of rice (Table 4). Penoxsulam tended to result in higher dry biomass and taller plants compared to other ALS-inhibiting herbicides and tended to elevate the weight of rice filled grains. No interaction effect was noted between herbicides and herbicide doses on unfilled grains. Averaged over doses, plants sprayed with pyrazosulfuron-ethyl and penoxsulam had less unfilled grains than those sprayed with ethoxysulfuron .

All herbicide treatments had similar reduced number of rice culm (32\%) compared to the weed-free plot (bentazon + carfentrazone-ethyl) (Table 5). The highest rice yields were $9.880 \mathrm{~kg} \mathrm{ha}^{-1}$ and $8.584 \mathrm{~kg} \mathrm{ha}^{-1}$ in 2008/09 and 2009/10, respectively, found with the tank mixture of bentazon + cafentrazoneethyl $\left(720+40 \mathrm{~g}\right.$ a.i. ha $\left.{ }^{-1}\right)$, which reached $100 \%$ control of globe fringerush. This was the 
weed-free standard. All ALS herbicides reduced the rice yield due to inadequate weed control (Figure 4). There was a significant interaction effect of herbicide $x$ dose $(p \leq 0.05)$ on rice yield

Table 3 - Rice injury analyzed at 28 days after herbicide application, related to weedy and weed-free (bentazon + carfentrazone-ethyl) checks, in Forquilhinha, Santa Catarina, Brazil, 2008/09

\begin{tabular}{|c|c|c|}
\hline Treatment & Dose $(\mathrm{X})$ & $\begin{array}{c}\text { Rice injury } \\
(\%)\end{array}$ \\
\hline \multirow{4}{*}{ Pyrazosulfuron-ethyl } & 0.5 & $3.2 \mathrm{def}$ \\
\hline & 1 & $4.2 \mathrm{de}$ \\
\hline & 2 & $3.2 \mathrm{edf}$ \\
\hline & 4 & 4.0 ed \\
\hline \multirow{4}{*}{ Bispyribac-sodium } & 0.5 & 0.6 ih \\
\hline & 1 & $0.6 \mathrm{ih}$ \\
\hline & 2 & 3.0 defg \\
\hline & 4 & $6.2 \mathrm{bc}$ \\
\hline \multirow{4}{*}{ Penoxsulam } & 0.5 & $2.2 \mathrm{fgh}$ \\
\hline & 1 & $4.0 \mathrm{ed}$ \\
\hline & 2 & $4.6 \mathrm{~cd}$ \\
\hline & 4 & $4.6 \mathrm{~cd}$ \\
\hline \multirow{4}{*}{ Ethoxysulfuron } & 0.5 & 1.4 ghi \\
\hline & 1 & $2.6 \mathrm{efg}$ \\
\hline & 2 & $6.6 \mathrm{~b}$ \\
\hline & 4 & $6.2 \mathrm{bc}$ \\
\hline Bentazon + carfentrazone-ethyl & $0.75+0.83$ & $9.4 \mathrm{a}$ \\
\hline Check (non-treated) & & $0.0 \mathrm{i}$ \\
\hline $\mathrm{CV}$ & & 36.0 \\
\hline
\end{tabular}

* Means within a column with the same uppercase letters do not differ by Fisher's test $(\mathrm{p} \leq 0.05)$.
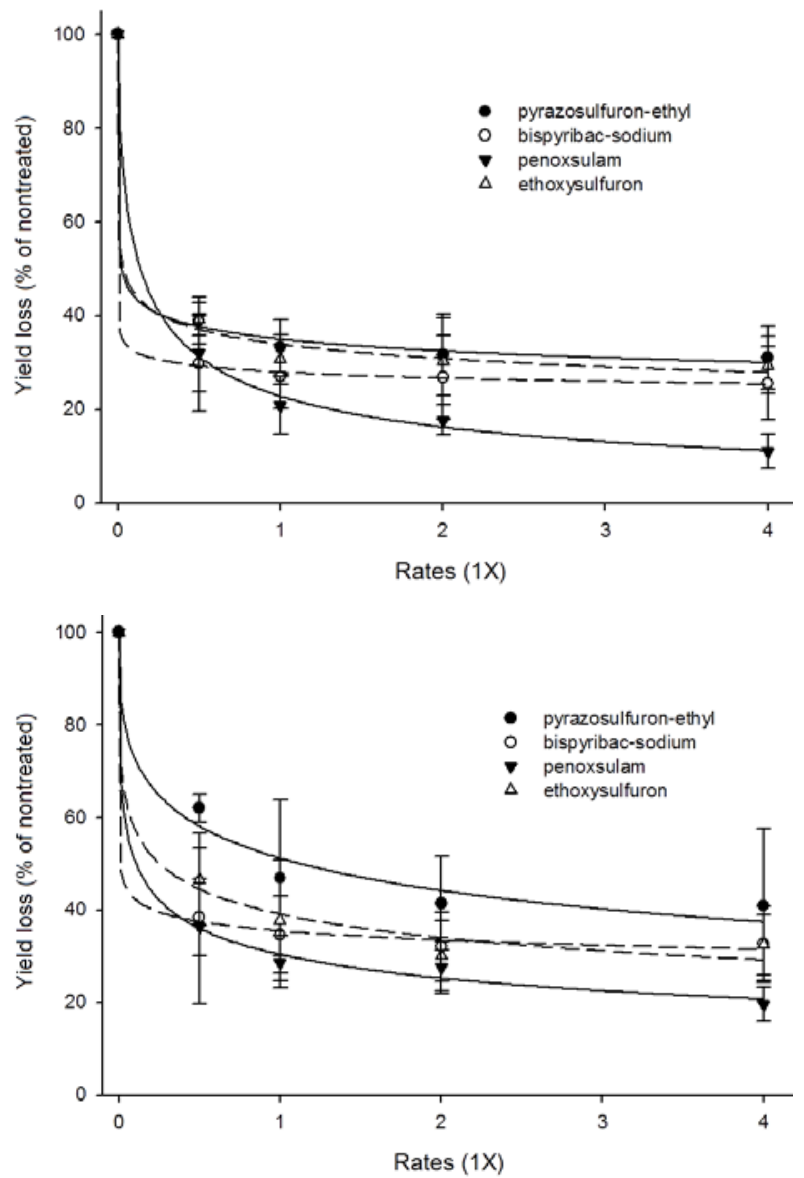

Figure 4 - Rice yield loss following POST applications of pyrazosulfuron-ethyl $(\bullet)$, bispyribac-sodium (o), penoxsulam $(\boldsymbol{\nabla})$, and ethoxysulfuron $(\Delta)$. Vertical bars represent the confidence interval $(\mathrm{p}<0.05)$. Experiments were conducted in the field, in Forquilhinha, Santa Catarina, Brazil, 2008/2009 and 2009/2010.

Table 4 - Filled and unfilled grains per panicle, plant height, and dry biomass of rice in competition with globe fringerush resistant to ALS-inhibiting herbicides, in Forquilhinha, Santa Catarina, Brazil 2008/09 and 2009/10

\begin{tabular}{|c|c|c|c|c|c|c|c|c|}
\hline \multirow[t]{2}{*}{ Treatment } & \multicolumn{2}{|c|}{$\begin{array}{c}\text { Filled grains } \\
\left.\text { (panicle }^{-1}\right)\end{array}$} & \multicolumn{2}{|c|}{$\begin{array}{l}\text { Unfilled grains } \\
\left(\text { panicle }^{-1}\right)\end{array}$} & \multicolumn{2}{|c|}{$\begin{array}{l}\text { Plant height } \\
(\mathrm{cm})\end{array}$} & \multicolumn{2}{|c|}{$\begin{array}{c}\text { Dry biomass } \\
\left(\mathrm{g} 0.25 \mathrm{~m}^{-2}\right)\end{array}$} \\
\hline & 08/09 & $09 / 10$ & $08 / 09$ & $09 / 10$ & $08 / 09$ & $09 / 10$ & 08/09 & $09 / 10$ \\
\hline Pyrazosulfuron-ethyl & 79 & 73 & $16 a^{*}$ & $16 a$ & 96 & 84 & 164 & 173 \\
\hline Bispyribac-sodium & 80 & 72 & $17 \mathrm{a}$ & $13 \mathrm{a}$ & 97 & 84 & 168 & 174 \\
\hline Penoxsulam & 81 & 77 & $16 \mathrm{a}$ & $14 \mathrm{a}$ & 97 & 83 & 183 & 179 \\
\hline Ethoxysulfuron & 80 & 76 & $18 \mathrm{a}$ & $16 \mathrm{a}$ & 97 & 83 & 159 & 171 \\
\hline Bentazon + carfentrazone-ethyl ${ }^{1 /}$ & 89 & 79 & $12 \mathrm{~b}$ & $7 \mathrm{~b}$ & 97 & 88 & 186 & 193 \\
\hline Non-treated & 79 & 71 & $16 \mathrm{a}$ & $15 \mathrm{a}$ & 99 & 87 & 178 & 163 \\
\hline Means & 81 & 75 & 16 & 14 & 97 & 85 & 173 & 175 \\
\hline $\operatorname{LSD}_{(0.05)}$ & NS & NS & 2.3 & 3.7 & NS & NS & NS & NS \\
\hline
\end{tabular}

1/ Weed-free standard. NS = Non significant by F test $(\mathrm{p} \leq 0.05) . *$ Means within a column with the same lowercase letters do not differ by Fischer's test $(\mathrm{p} \leq 0.05)$. 
(Table 6). The lowest dose of bispyribac-sodium and ethoxysulfuron resulted in the highest yield loss of 29.7 to $39.1 \%$ in the first year. The lowest dose of penoxsulam and pyrazosulfuronethyl resulted in the highest yield loss of 36.4 to $61.9 \%$ in the second year. These treatments allowed the most weed interference with rice. At the maximum dose (4X) of the selector herbicide, pyrazosulfuron-ethyl, rice yield loss was 31.0 and $40.9 \%$ on average, respectively, for year 1 and 2 . The different levels of weed resistance to ALS inhibitors, which resulted in different levels of weed control, were also associated with different levels of rice yield loss among treatments. The highest dose of penoxsulam caused the lowest yield loss, of about $11 \%$ in the first year and $20 \%$ in the second year.

There was earlier evidence that the population infesting this location (Noldin, et al., 2002) had cross-resistance to three chemical groups of ALS inhibitors: sulfonylurea, pyrimidylthiobenzoates and triazolopyrimidines; agreeing with this present study (Figure 2 and 3 ). The crossresistance to different families of ALS inhibitors commonly occurs, for instance in ALS-resistant Amaranthus palmeri (Burgos et al., 2001), Bidens subalternans (Lamego et al., 2009), Cyperus difformis (Merotto Jr. et al., 2009) and many others. Imidazolinone herbicides are also labeled for Clearfield ${ }^{\circledR}$ rice in Brazil. This herbicide family was not included in this study because the rice cultivar planted was not imidazolinone-resistant (Clearfield ${ }^{\circledR}$ rice).

The dose-response curves were generated using the sigmoidal log-logistic model (Seefeldt et al., 1995). In this experiment, the resistance factor to various herbicides could not be determined because there was no susceptible population; however, the

Table 5 - Number of culm $\left(\mathrm{m}^{-2}\right)$ of rice in competition with globe fringerush resistant to ALS-inhibiting herbicides, in Forquilhinha, Santa Catarina, Brazil, 2008/09 and 2009/10

\begin{tabular}{|c|c|c|c|c|c|c|c|c|}
\hline \multirow{2}{*}{ Dose $^{1 /}$} & \multicolumn{2}{|c|}{ Pyrazosulfuron-ethyl } & \multicolumn{2}{c|}{ Bispyribac-sodium } & \multicolumn{2}{c|}{ Penoxsulam } & \multicolumn{2}{c|}{ Ethoxysulfuron } \\
\cline { 2 - 9 } & $08 / 09$ & $09 / 10$ & $08 / 09$ & $09 / 10$ & $08 / 09$ & $09 / 10$ & $08 / 09$ & $09 / 10$ \\
\hline $0.5 \mathrm{X}$ & $528^{*}$ & $540^{*}$ & $592^{*}$ & $529^{*}$ & $560^{*}$ & $504^{*}$ & $576^{*}$ & $551^{*}$ \\
\hline $1 \mathrm{X}$ & $536^{*}$ & $538^{*}$ & $552^{*}$ & $520^{*}$ & $520^{*}$ & $510^{*}$ & $552^{*}$ & $550^{*}$ \\
\hline $2 \mathrm{X}$ & $520^{*}$ & $496^{*}$ & $616^{*}$ & $463^{*}$ & $600^{*}$ & $546^{*}$ & $504^{*}$ & $496^{*}$ \\
\hline $4 \mathrm{X}$ & $576^{*}$ & $473^{*}$ & $496^{*}$ & $488^{*}$ & $568^{*}$ & $506^{*}$ & $568^{*}$ & $528^{*}$ \\
\hline Weed-free & \multicolumn{3}{|c|}{$794(2008 / 09)$} & \multicolumn{5}{|c|}{$788(2009 / 10)$} \\
\hline LSD & $91(2008 / 09)$ & & \multicolumn{6}{c|}{$10909 / 10)$} \\
\hline
\end{tabular}

${ }^{1 /}$ The $1 \mathrm{X}$ doses are: pyrazosulfuron $=17.5 \mathrm{~g}$ a.i. ha $^{-1}$; bispyribac $=50 \mathrm{~g}$ a.i. ha ${ }^{-1}$; penoxsulam $=30 \mathrm{~g}$ a.i. ha $^{-1}$; ethoxysulfuron $=80 \mathrm{~g}$ a.i. ha ${ }^{-1}$.

* Significant difference compared to the weed-free check using the Dunnett's test $(\mathrm{p} \leq 0.05)$.

Table 6 - Regression parameters ${ }^{1 /}$ to estimate the herbicide dose that will result in $50 \%$ yield loss of rice, in Forquilhinha, Santa Catarina, Brazil, 2008/09 and 2009/2010

\begin{tabular}{|l|c|c|c|c|c|}
\hline \multicolumn{1}{|c|}{ Herbicide $^{2 /}$} & Season & $\mathrm{a}$ & $\mathrm{b}$ & $\mathrm{YL}_{50^{3}}$ & $\mathrm{R}^{2}$ \\
\hline \multirow{2}{*}{ Pyrazosulfuron-ethyl } & $2008 / 09$ & 100 & 0.17 & 0.02 & 0.99 \\
\cline { 2 - 7 } & $2009 / 10$ & 100 & 0.40 & 1.11 & 0.97 \\
\hline \multirow{2}{*}{ Bispyribac-sodium } & $2008 / 09$ & 100 & 0.09 & 0.01 & 0.99 \\
\cline { 2 - 7 } & $2009 / 10$ & 100 & 0.12 & 0.01 & 0.99 \\
\hline \multirow{2}{*}{ Penoxsulam } & $2008 / 09$ & 100 & 0.62 & 0.13 & 0.99 \\
\cline { 2 - 7 } & $2009 / 10$ & 99.9 & 0.37 & 0.11 & 0.99 \\
\hline \multirow{2}{*}{ Ethoxysulfuron } & $2008 / 09$ & 100 & 0.02 & 0.04 & 0.99 \\
\cline { 2 - 7 } & $2009 / 10$ & 100 & 0.32 & 0.25 & 0.99 \\
\hline
\end{tabular}

${ }^{1 /}$ Log-logistic equation: $\mathrm{Y}=$ a D $\left(1+(\mathrm{X}-\mathrm{X} 0)^{\mathrm{b}}\right) .(\mathrm{p}<0.001) .{ }^{2 /}$ The $1 \mathrm{X}$ doses are: pyrazosulfuron $=17.5 \mathrm{~g}$ a.i. ha ${ }^{-1}$; bispyribac $=50 \mathrm{~g}$ a.i. ha ${ }^{1}$; penoxsulam $=30 \mathrm{~g}$ a.i. ha ${ }^{-1}$; ethoxysulfuron $=80 \mathrm{~g}$ a.i. ha $^{-1} \cdot{ }^{3 /}$ Herbicide dose that could reduce rice yield by $50 \%$. 
experiment demonstrated cross-resistance to different families of ALS inhibitors. Weed control was lower than $62 \%$ in the first and second analyses, regardless of the ALS herbicide used. Furthermore, globe fringerush control declined at 28 and 70 DAA, indicating recovery from herbicide damage. On susceptible populations, bispyribac-sodium has satisfactory activity on a number of damaging weeds, including grasses (Echinochloa crusgalli, E. colonum), broadleaves (Sagittaria montevidensis, Ludwigia spp.) and sedges (globe fringerush) and is highly selective to rice. Pyrazosulfuron-ethyl is equally effective to bispyribac-sodium in controlling globe fringerush, but pyrazosulfuron-ethyl could have some phytotoxic effects on rice, such as stunting and reduced number of grains per panicle (Begum et al., 2008).

In general, ALS herbicides do not cause injury to rice and that was noted in this experiment. The same experiment by Begum et al. (2008) also showed that bispyribacsodium increased the number of rice grains per panicle. In this present study all herbicide treatments failed to increase the number of rice culm due to intense competition with globe fringerush. On an ALS-susceptible population, bentazon and pyrazosulfuron-ethyl controlled globe fringerush and produced higher total number of culm $\mathrm{m}^{-2}$ than rice treated with bispyribac-sodium (Begum et al., 2008). The ALS herbicides did not generally reduce the number of filled grains in the current study, nor in previous related research (Begum et al., 2003).

The practice of rotating herbicides of the same mechanism of action, such as bispyribacsodium, penoxsulam and ethoxysulfuron, cannot control resistant globe fringerush. The use of other modes of action, such as bentazon, carfentrazone-ethyl, or a mixture of these, can be an alternative control of globe fringerush. On the other hand, it is important to consider that this approach is not foolproof. In other regions worldwide and in Brazil, weed populations with multiple resistance to herbicides with different modes of action have evolved. For example, a biotype of Sagittaria montevidensis, another major weed in rice, was reported to have multiple resistance to ALSinhibitors and PSII inhibitors in Santa
Catarina (Eberhardt \& Noldin, 2011). In California, USA, Echinochloa oryzoides and E. phyllopogon showed multiple resistance to bispyribac-sodium, thiobencarb, molinate, fenoxaprop-ethyl, and propanil herbicides in rice field (Fischer et al., 2000), and Echinochloa crus-galli with multiple resistance to ALS and ACCase inhibitors in South Korea (Heap, 2012).

We conclude that the globe fringerush biotype infesting this location in Santa Catarina, Brazil, is cross-resistant to ALSinhibitor herbicides pyrazosulfuron-ethyl (SU), penoxsulam (TP), bispyribac-sodium (PTB), and ethoxysulfuron (SU). Alternative methods of weed control and general crop production practices should be adopted to prevent the continued evolution of globe fringerush resistance, or other weeds, to ALS inhibitors in irrigated rice areas in Brazil.

\section{ACKNOWLEDGEMENTS}

The authors thank the farmer Mr. Marcelino Schmitt, for allowing us to use his rice field farm for this research, and the National Council for Scientific and Technological Development (CNPq) for the scholarship they have granted to the first author.

\section{LITERATURE CITED}

BEGUM, M. K. et al. Effect of herbicides on different crop characters used in controlling weeds of Aman rice grown under wet seeded culture. Pakistan J. Agron., v. 2, n. 1, p. 44-51, 2003.

BEGUM, M. K. et al. Effect of herbicides for the control of Fimbristylis miliacea (L.) Vahl. in rice. J. Agron., v. 7, n. 3, p. 251-257, 2008.

BURGOS, N. R.; KUK, Y.; TALBERT, R. E. Amarathus palmeri resistance and differential tolerance of Amaranthus palmeri and Amaranthus hybridus to ALS inhibitor herbicides. Pest. Manag. Sci., v. 57, n. 5, p. 449-457, 2001.

EBERHARDT, D. S.; NOLDIN, J. A. Multiple herbicideresistant Sagittaria montevidensis population in Santa Catarina State (Brazil) rice fields. In: WEED SCIENCE SOCIETY OF AMERICA, 15., 2011, Portland. Proceedings... Portland: Weed Science Society of America, 2011. p. 9.

FISCHER, A. J. et al. Herbicide-resistant Echinochloa oryzoides and E. phyllopogon in California Oryza sativa fields. Weed. Sci., v. 48, n. 2, p. 225-230, 2000. 
HEAP, I. International Survey of Herbicide Resistant Weeds. Available at: < http://www.weedsciencHYPERLINK "http://www.weedscience.com/”e.com>. Accessed: Octob. 17, 2012.

INSTITUTO BRASILEIRO DE GEOGRAFIA E ESTATÍSTICA - IBGE. Indicadores - Levantamento sistemático da produção agrícola. Safra 2011. Available at: <http://www.ibge.gov.br>. Accessed: Octob. 17, 2012.

KISSMANN, K. G., (Ed.). Plantas infestantes e nocivas. 3.ed. São Paulo: Basf Brasileira, 2007. Tomo I. CD ROM.

LAMEGO, F. P. et al. Cross-resistance of Bidens subalternans to acetolactate synthase inhibitors in Brazil. Weed Res., v. 49, n. 6, p. 634-641, 2009.

MASSA, D.; KRENZ, B.; GERHARDS, R. Target-site resistance to ALS-inhibiting herbicides in Apera spica-venti populations is conferred by documented and previously unknown mutations. Weed Res., v. 51, n. 3, p. 294-303, 2011.

MEROTTO JR., A. et al. Cross-resistance to herbicides of five ALS-inhibiting groups and sequencing of the ALS gene in Cyperus difformis L. J. Agric. Food Chem., v. 57, n. 4, p. 1389-1398, 2009.

NOLDIN, J. A.; EBERHARDT, D. S.; RAMPELOTTI, F. T. Fimbristylis miliacea (L.) Vahl resistente a herbicidas inibidores da ALS em Santa Catarina. In: CONGRESSO BRASILEIRO DA CIÊNCIA DAS PLANTAS DANINHAS, 2002, Gramado. Proceedings... Gramado: Embrapa Clima Temperado, 2002. p. 199.
NOLDIN, J. A. Eficácia do herbicida bispyribac sodium (Nominee) no controle de plantas daninhas em arroz irrigado. Lav. Arroz., v. 50, n. 431, p. 15-19, 1997.

SEEFELDT, S. S.; JENSEN, J. E.; FUERST, E. P. Log-logistic analysis of herbicide dose-response relationships. Weed Technol., v. 9, n. 2, p. 218-227, 1995.

SOIL SURVEY STAFF. United States Department of Agriculture. Natural Resources Conservation Service. Keys to soil taxonomy. 9.ed. Washington: 2003. 332 p.

REUNIÃO Técnica da Cultura do Arroz Irrigado: Recomendações Técnicas da Pesquisa para o Sul do Brasil. Sociedade Sul-Brasileira de Arroz Irrigado. Pelotas: Universidade Federal de Pelotas, 2007. 161 p.

Reunião Técnica da Cultura do Arroz Irrigado: Recomendações Técnicas da Pesquisa para o Sul do Brasil. Sociedade Sul-Brasileira de Arroz Irrigado. Pelotas: Universidade Federal de Pelotas, 2012. 179 p.

.TRANEL, P. J.; WRIGHT, T. R. Resistance of weeds to ALS-inhibiting herbicides: what have we learned? Weed Sci., v. 50, n. 6, p. 700-712, 2002.

VIDAL, R. A.; LAMEGO, F. P.; TREZZI, M. M. Diagnóstico da resistência aos herbicidas em plantas daninhas. Planta Daninha, v. 24, n. 3, p. 597-604, 2006.

VIDAL, R. A.; MEROTTO JR., A.. Herbicidologia. Porto Alegre: Evangraf, 2001. p.152.

YASUOR, H. et al. Mechanism of resistance to penoxsulam in late watergrass (Echinochloa phyllopogon). J. Agric. Food Chem. v. 57, n. 9, p. 3653-3660, 2009. 